\title{
Does anthropogenic nitrogen deposition induce phosphorus limitation in herbivorous insects?
}

\author{
LEILING TAO and MARK D. HUNTER \\ Department of Ecology and Evolutionary Biology, University of Michigan, 2086 Kraus Natural Sciences Building, 830 North \\ University Avenue, Ann Arbor, MI 48109-1048, USA
}

\begin{abstract}
Anthropogenic nitrogen deposition has shifted many ecosystems from nitrogen $(\mathrm{N})$ limitation to phosphorus $(\mathrm{P})$ limitation. Although well documented in plants, no study to date has explored whether $\mathrm{N}$ deposition exacerbates $\mathrm{P}$ limitation at higher trophic levels, or focused on the effects of induced plant $\mathrm{P}$ limitation on trophic interactions. Insect herbivores exhibit strict $\mathrm{N}: \mathrm{P}$ homeostasis, and should therefore be very sensitive to variations in plant $\mathrm{N}: \mathrm{P}$ stoichiometry and prone to experiencing deposition-induced P limitation. In the current study, we investigated the effects of $\mathrm{N}$ deposition and $\mathrm{P}$ availability on a plant-herbivorous insect system. Using common milkweed (Asclepias syriaca) and two of its specialist herbivores, the monarch caterpillar (Danaus plexippus) and milkweed aphid (Aphis asclepiadis) as our study system, we found that experimental $\mathrm{N}$ deposition caused $\mathrm{P}$ limitation in milkweed plants, but not in either insect species. However, the mechanisms for the lack of $P$ limitation were different for each insect species. The body tissues of $A$. asclepiadis always exhibited higher $\mathrm{N}$ : P ratios than that of the host plant, suggesting that the $\mathrm{N}$ demand of this species exceeds $\mathrm{P}$ demand, even under high $\mathrm{N}$ deposition levels. For $D$. plexippus, $\mathrm{P}$ addition increased the production of latex, which is an important defense negatively affecting $D$. plexippus growth rate. As a result, we illustrate that $\mathrm{P}$ limitation of herbivores is not an inevitable consequence of anthropogenic $\mathrm{N}$ deposition in terrestrial systems. Rather, species-specific demands for nutrients and the defensive responses of plants combine to determine the responses of herbivores to $\mathrm{P}$ availability under $\mathrm{N}$ deposition.
\end{abstract}

Keywords: anthropogenic phosphorus limitation, Asclepias syriaca, N : P stoichiometry, nitrogen deposition, phosphorus, plant defense, plant-herbivore interactions

Received 15 November 2011 and accepted 24 December 2011

\section{Introduction}

In the last few decades, agricultural fertilization and fossil fuel combustion have changed the global nitrogen (N) cycle, resulting in significant atmospheric $\mathrm{N}$ deposition to ecosystems worldwide (Vitousek et al., 1997). Increased $\mathrm{N}$ input has initially enhanced plant photosynthesis and productivity (Aber et al., 1989). However, as the principle of ecological stoichiometry states, it is the relative balance between essential elements, not their absolute amount, which should predict organismal performance (Sterner \& Elser, 2002). As N levels continue to rise and $\mathrm{N}$ limitation is subsequently alleviated, many plants are becoming more limited by other elements, most notably phosphorus (P; Bobbink et al., 2010). This 'anthropogenic P limitation' (Vitousek et al., 2010; Peñuelas et al., 2012) has been documented in several temperate and tropical ecosystems, and is believed to be an important mechanism underlying changes in plant community composition (Bobbink et al., 2010) and ecosystem processes under nitrogen deposition,

Correspondence: Leiling Tao, tel. + 1734277 1371, fax + 1734763 0544, e-mail: leiltao@umich.edu including changes in net primary production and nutrient retention (Aber et al., 1989).

Nitrogen is an essential building block of the tissues of insect herbivores (Mattson, 1980). On average, insect body $\mathrm{N}$ concentrations are 10 times higher than those of host plants, therefore nitrogen deposition has resulted in higher fitness and abundance of many herbivorous insects (Throop \& Lerdau, 2004). However, because $\mathrm{P}$ has not been manipulated independently in these previous studies, effects of $\mathrm{N}$ on insects cannot be separated from effects caused by changes in $\mathrm{N}: \mathrm{P}$ ratios. Indeed, $\mathrm{P}$ is a key constituent of nucleic acids and enzymes, the limitation of which affects many aspects of insect performance, including survival (Clancy \& King, 1993), body size (Huberty \& Denno, 2006), development (Perkins et al., 2004), growth rate (Watts et al., 2006) and sexual and oviposition behavior (Bertram et al., 2006). While evidence for anthropogenic $P$ limitation in plants is accumulating rapidly, there has been no exploration to date on whether $\mathrm{P}$ limitation is also increasing in insects. Compared with plants, heterotrophs have very high levels of stoichiometric homeostasis (Persson et al., 2010; Sardans et al., 2011), and deviations from optimal dietary elemental ratios 
will change insect foraging behavior (Raubenheimer \& Simpson, 1997) and/or postingestion assimilation (Woods et al., 2002), both of which are energy consuming processes. While there is no simple way of determining optimal dietary $\mathrm{N}: \mathrm{P}$ ratio for herbivorous insects, using body $\mathrm{N}$ : P ratio as a proxy can be useful (Hillebrand et al., 2009). Therefore, insect performance should exhibit a hump shaped curve in relation to the stoichiometric mismatch between insect and plant tissues, with the highest insect performance achieved when the match is perfect. A survey of more than 300 species of terrestrial plants and 20 species of herbivorous insects has shown that on average, $\mathrm{N}$ : $\mathrm{P}$ ratios of insects are lower than those of plants, indicating that $\mathrm{P}$ limitation should be at least as severe as $\mathrm{N}$ limitation for herbivores (Elser et al., 2000). As plants always exhibit higher $\mathrm{N}$ : P ratios under increased $\mathrm{N}$ inputs (Morecroft et al., 1994), this stoichiometric mismatch will be exacerbated further toward P limitation under $\mathrm{N}$ deposition.

While increased $\mathrm{P}$ limitation in insects by $\mathrm{N}$ deposition seems theoretically inevitable, we need to consider two other factors. First, insect species differ greatly in their body $\mathrm{N}$ and $\mathrm{P}$ contents. For example, Lepidoptera have the lowest $\mathrm{N}$ and highest $\mathrm{P}$ concentrations (and therefore the highest potential for $\mathrm{P}$ limitation) when compared with other insect orders (Fagan et al., 2002; Woods et al., 2004), whereas Hemiptera are considered to be extremely $\mathrm{N}$ limited (Speight et al., 2008). As a result, potential $\mathrm{P}$ limitation may vary with the specific requirements of different herbivore taxa. Second, nutrient stoichiometry affects plant physical and chemical defenses (Karban \& Baldwin, 1997). Theoretic and empiric studies of plant defense have documented that major defense chemicals vary with $\mathrm{N}$ availability (Bryant et al., 1983; Herms \& Mattson, 1992; Koricheva et al., 1998). In contrast, data on the relationship between plant $\mathrm{P}$ and defense expression are less extensive (Koricheva et al., 1998). While early theories of plant defense have focused on carbon-nutrient balance and growth/defense differentiation, biochemical studies provide a more mechanistic understanding of links between nutrient availability and plant defense. Cellular molecules containing inorganic phosphorus (Pi) are the most vulnerable P-containing molecules under $\mathrm{P}$ deficiency (Hidaka \& Kitayama, 2011). The concentration of $\mathrm{Pi}$ is actively maintained by metabolic pathways (Plaxton \& Carswell, 1999), such as upregulating chorismate synthesis, which can generate 4 molecules of $\mathrm{Pi}$ at the expense of 1 erythrose-4-P, 1 ATP and 2 PEP molecules (Fischer et al., 1993). As chorismate is the precursor for phenylalanine, which is the precursor of phenolics in the shikimate pathway (Jones \& Hartley, 1999), P limitation can indirectly induce higher total phenolic defenses. However, the opposite trend is also found in some plant species. Rhizophora mangle for example, has lower concentrations of condensed tannins and total phenolics under $\mathrm{P}$ limitation (Feller, 1995). These mixed results illustrate the complex interplay and context dependence of carbon, nitrogen and phosphorus metabolism. It is worth pointing out that the studies cited above mimicked $\mathrm{P}$ limitation under natural conditions, but no study so far has aimed at correlating anthropogenic $\mathrm{P}$ limitation with plant defense expression. If anthropogenic $\mathrm{P}$ limitation decreases defense production in plants, any direct negative consequences of $\mathrm{P}$ limitation on insects may be offset by positive indirect effects mediated by reductions in plant defense. In contrast, effects of $\mathrm{P}$ limitation on insects may be particularly severe if P-limited plants also accumulate higher concentrations of defense chemicals. As a result, effects of $\mathrm{P}$ availability on insects under $\mathrm{N}$ deposition will depend on the directions and relative importance of stoichiometric mismatch and plant defense on insect performance.

To explore direct and indirect effects of anthropogenic P limitation on insect herbivores, we performed a greenhouse experiment with the common milkweed (Asclepias syriaca) and two specialist insect herbivores: monarch caterpillars (Danaus plexippus) and aphids (Aphis asclepiadis). A lepidopteran and a hemipteran species were selected because they are likely to differ in their $\mathrm{N}$ and $\mathrm{P}$ requirements (see elsewhere in the article). Milkweed plants were cross-fertilized with ammonium nitrate and calcium phosphate monobasic to simulate anthropogenic nitrogen deposition and to create a phosphorus gradient within natural ranges. We explored potential P limitation in insects by correlating stoichiometric mismatch with performance of each insect species. We also explored the role of plant defense expression as a mediator. To our knowledge, this is the first attempt to investigate the potential effects of anthropogenic P limitation on trophic interactions under the dual frameworks of ecological stoichiometry and plant defense theory.

\section{Materials and methods}

\section{Study system}

The common milkweed (Asclepias syriaca) is a widespread native plant in eastern North America. Milkweeds reproduce both sexually and asexually and host about 12 species of insect herbivore in the eastern United States. A. syriaca populations have shown inconsistent response to $\mathrm{N}$ deposition (Pennings et al., 2005), perhaps because of P colimitation (Zehnder \& Hunter, 2009). Putative defenses in A. syriaca include cardenolides, latex and trichomes. Cardenolides are toxic steroids that can 
interfere with $\mathrm{Na}^{+} / \mathrm{K}^{+}$-ATPase channels in animal cells, and can be negatively correlated with insect performance and lethal for mammals (Harborne, 1991). Latex is a white sticky fluid stored in high pressure nonarticulated laticifers. In the genus Asclepias, latex is primarily composed of cardenolides, amyrin and cis-polyisoprene (Emon \& Seiber, 1985). In comparison to leaf cardenolides, latex cardenolides occur at much higher concentrations (2-200 times) and are composed of more lowpolarity cardenolides (Seiber et al., 1982). Trichomes are glandular hairs that cover both the upper and lower lamina and can deter insect feeding (Levin, 1973). The synthesis of cardenolides and latex require many phosphorus intermediates and the storage of latex in laticifers demands large amounts of ATP (Gershenzon, 1994). Therefore, we predicted that chemical defenses in milkweed would be phosphorus limited.

The monarch butterfly (Danaus plexippus) is a specialist herbivore on the genus Asclepias. Larvae feed on milkweed leaves for 10-12 days before pupating. Significantly, latex can reduce the survival rate of monarch larvae and they have evolved the behavior of trenching or severing leaf petioles before feeding (Zalucki \& Malcolm, 1999). The milkweed aphid (Aphis asclepiadis) is a gregarious phloem feeding insect that feeds preferentially on apical leaves. Aphids generally undergo several parthenogenetic generations before sexual reproduction, sometimes resulting in more than 1000 individuals on a single milkweed ramet.

\section{Greenhouse experiment}

Milkweed seeds were collected from a natural milkweed population at the University of Michigan Biological Station in Pellston, MI in September 2009. Seeds were stored in a refrigerator at $4{ }^{\circ} \mathrm{C}$ until use. At the end of April 2010, seeds were cold stratified for 6 weeks and then germinated on damp filter paper in petri dishes at $25{ }^{\circ} \mathrm{C}$. After germination, 500 seedlings were planted in 4 inch plant pots containing a $1: 1: 1$ mixture of potting soil (SunGrow Horticulture, Vancouver, BC, Canada), sand (Kolorscape) and perlite (Miracle-Gro, Marysville, $\mathrm{OH})$. They were then transported to a greenhouse at Matthaei Botanic Garden, Ann Arbor, MI. When the plants were 3-weeks old, 10 by 10 levels of nitrogen and phosphorus fertilizer were applied in a factorial design across plants (100 nutrient combinations $\times 5$ replicates each $=500$ plants) Nitrogen was added as ammonium nitrate at levels of $0,0.8$, 1.6, 2.4, 3.2, 4, 4.8, 5.6, 6.4, $7.2 \mathrm{~g} \mathrm{~m}^{-2} \mathrm{yr}$, and phosphorus was added as calcium phosphate monobasic at levels of $0,0.16$, $0.32,0.48,0.64,0.8,0.96,1.12,1.28,1.44 \mathrm{~g} \mathrm{~m}^{-2} \mathrm{yr}$. The $\mathrm{N}$ levels were selected to mimic predicted estimates of $\mathrm{N}$ deposition throughout the range of our insect species (Galloway et al., 2004), and P levels were chosen based on the fact that the $\mathrm{N}$ : P ratio in milkweed is around 6 to 7 (Zehnder \& Hunter, 2009). As a result, the experiment was designed to simulate current and future $\mathrm{N}$ deposition, whereas generating plant $\mathrm{P}$ levels within natural ranges. Fertilizer was applied once every week for a total of 5 weeks. We expected some plant mortality, and we chose this design to ensure that we generated milkweed plants with a broad range of $\mathrm{N}: \mathrm{P}$ stoichiometry for experiments with insects (elsewhere in the text). Ultimately, we used two plants from each nutrient treatment for experiments with caterpillars $(n=200)$ and one plant from each nutrient treatment for experiments with aphids $(n=100)$. This reflects a regression design rather than a replicated factorial design.

Starting 1 week after the last fertilization, we measured the physical and chemical traits of the plants that we subsequently used in experiments with insects. For logistical reasons, there was a 5-day gap between the start of the experiments with monarchs (1 week after the last fertilization) and the experiments with aphids (12 days after the last fertilization), thus these experiments have been analyzed separately. We measured change in plant height between the first fertilization and the start of herbivore treatment as an index of plant growth. One leaf from the fourth leaf pair of each plant was harvested for chemical analysis. Specifically, six leaf disks (total $424 \mathrm{~mm}^{2}$ ) were taken by a paper punch from one side of the leaf, placed immediately into $1 \mathrm{~mL}$ of cold methanol and stored at $-10{ }^{\circ} \mathrm{C}$ for subsequent cardenolide analysis. Another six identical disks were taken from the opposite side of the same leaf and stored in glassine envelopes to estimate sample dry mass and to estimate trichome density. We used a dissecting microscope at $4 \times$ magnification with an optical micrometer to count trichomes on both the upper and lower surfaces of each leaf disk. The numbers were then averaged to a single value for each plant. We collected latex that exuded from the first six hole punches on preweighed cellulose disks $(1 \mathrm{~cm}$ diameter), that were subsequently dried and reweighed. The whole leaf was then removed from the plant, dried at $70{ }^{\circ} \mathrm{C}$ for $72 \mathrm{~h}$, and ground into fine powder for nutrient analysis.

Monarch eggs were purchased from the Butterfly Rescue International Association in Allenton, MI. They were stored in a refrigerator for 2 days to synchronize hatching. Around 200 aphids were collected from the Edwin S. George Reserve, Pinckney, MI. Insects were introduced onto plants immediately after chemical sampling. One newly hatched monarch larva was placed on each of 200 plants (elsewhere in the text). Two aphids were introduced onto each of another 100 plants. The herbivores were confined to each plant by mesh bags. After 7 days of feeding, surviving herbivores were retrieved and kept in petri dishes at room temperature for $48 \mathrm{~h}$ to void their gut contents. By 7 days, most of the monarch larvae had entered the fourth instar and aphids had completed one full generation (Mooney et al., 2008). To measure insect performance, monarch larval dry mass was measured on a microbalance (Mettler Toledo, Columbus, OH, USA), and numbers of aphids were counted to estimate aphid population growth. Perhaps due to 2 days of very hot weather during the experiments, the survival rates of the insects were moderate (114 out of 200 monarchs, aphids on 83 out of 100 plants). Due to logistical constraints, we could not run chemical analyses on all herbivore individuals used in our experiments. However, it is generally agreed that animals are much more strictly homeostatic than are plants (Persson et al., 2010; Sardans et al., 2011). Therefore, we chose only a subset of total insect samples for chemical analysis. These samples allowed us to (i) verify that insects do indeed show elemental homeostasis across a broad range of nutrient availabilities, and (ii) estimate average $\mathrm{N}$ 
and $\mathrm{P}$ concentrations of our insects by which we could calculate their elemental mismatch with the treatment plants upon, which they were fed. To select caterpillars, we first retrieved all of them from their treatment plants, placed them in individual petri dishes, and marked each petri dish with its treatment level. We then selected every sixth caterpillar from the total of 114 individuals, providing 19 individuals for chemical analysis covering the entire range of treatments. In contrast to caterpillars, aphids were considered as populations on plants and not collected individually. Rather, after removing aphid populations from their plants, we selected every eighth population from the total of 83 populations (plants) for a total of 10 aphid populations for chemical analysis.

\section{Chemical analysis}

Analysis of foliar cardenolide content followed Vannette \& Hunter (2011a). Briefly, leaf disks were ground for $3 \mathrm{~min}$ in methanol using a ball mill and sonicated at $60{ }^{\circ} \mathrm{C}$ for $1 \mathrm{~h}$. The supernatant was evaporated at $45^{\circ} \mathrm{C}$ for $70 \mathrm{~min}$ until dryness. Samples were resuspended in $150 \mu \mathrm{L}$ methanol containing $0.15 \mathrm{mg} \mathrm{mL}^{-1}$ digitoxin as an internal standard and analyzed using reverse phase high-performance liquid chromatography at high system pressures (UPLC, Waters Inc., Milford, MA, USA). Running time for each sample was $9 \mathrm{~min}$. Peaks were detected by absorption at $218 \mathrm{~nm}$ using a diode array detector, and absorbance spectra were recorded from 200 to $300 \mathrm{~nm}$ with digitoxin as the standard. Peaks with symmetric absorption maxima between 216 and $222 \mathrm{~nm}$ were recorded as cardenolides. Total cardenolide concentration was calculated as the sum of all separated cardenolide peaks, corrected by the concentration of the internal standard and the estimated sample mass. Carbon and $\mathrm{N}$ contents in plant and insect tissues were measured on a CHN analyzer (Costech, Valencia, CA, USA) and $\mathrm{P}$ contents were quantified by an autoanalyzer using an acid digestion method. Plant and insect N : P ratio was calculated as molar ratio.

\section{Statistical analysis}

We used general linear models (GLM) to assess the effects of $\mathrm{N}$ and $\mathrm{P}$ fertilization and their interaction on foliar $\mathrm{N}$ and $\mathrm{P}$ concentrations and plant growth. Because the aphid and caterpillar experiments were not performed simultaneously, we generated separate analyses for each experiment. Following the methods of Sterner \& Elser (2002) of regressing plant N : P ratios with those of the insects, we confirmed that both $D$. plexippus and $A$. asclepiadis exhibited strict body elemental homeostasis (slope for D. plexippus is $0.19, F_{1,17}=0.328$, $P=0.575$; slope for $A$. asclepiadis is $0.16, \quad F_{1,8}=0.512$, $P=0.495$ ). As both slopes are less than 0.25 , they also fit the criteria of Persson et al. (2010) for homeostasis. Therefore, we used the average $\mathrm{N}: \mathrm{P}$ ratio of each herbivore species in calculating the stoichiometric mismatch between plants and herbivores in all following analyses.

To test the individual and interactive effects of plant $\mathrm{N}$ and $P$ on insect performance, we used GLM with plant $\mathrm{N}$ and $\mathrm{P}$ as independent variables and insect performance (mass for
D. plexippus and numbers for A. asclepiadis) as dependent variables. In addition, we hypothesized that insect performance would respond nonlinearly to the $\mathrm{N}$ : P mismatch between plants and insect, with highest insect performance achieved when the match was perfect. Therefore, we examined both linear and quadratic model fits between insect-plant N : P mismatch and insect performance. Specifically, we subtracted the $\log$ of the N : P ratio of each individual plant from the log of the average $\mathrm{N}: \mathrm{P}$ ratio of aphids or monarchs to calculate the $\mathrm{N}$ : P mismatch between insects and individual plants. Mismatch was then the independent variable and insect performance was the dependent variable.

Measures of model fit including AIC and $R^{2}$ were extracted from each model. Model selection was performed using AIC, where differences in AIC $>2$ were deemed an improved fit (Burnham \& Anderson, 2002). We used GLM to test the individual and interactive effects of plant $\mathrm{N}$ and $\mathrm{P}$ on each defense trait.

We then used path analysis to compare the relative strengths of direct (stoichiometric) and indirect (via plant defense) effects of $\mathrm{N}$ and $\mathrm{P}$ on insect performance. We began the modeling exercises by first constructing a saturated model for each species in which $\mathrm{N}$ and $\mathrm{P}$ were exogenous variables, and latex, cardenolides and trichomes were endogenous predictors of insect performance. We also allowed correlations between exogenous variables. We then iteratively set the least significant path to zero and examined whether removal of the path increased model fit, as judged by AIC. We continued this process until we arrived at the most parsimonious model. For A. asclepiadis, the most parsimonious path model excluded all three defense traits, and therefore reduced to the relationships among foliar nutrients and aphid performance under GLM (elsewhere in the article).

Before all statistical analysis, data were evaluated by Kolmogorov-Smirnov tests for normality, and were log transformed when necessary. The path analysis was conducted in Amos 18 (SPSS Inc, Chicago, Illinois), and GLM were conducted in the GLM package in R 2.13.2 (R Development Core team 2011).

\section{Results}

\section{Plant nutrient content and plant growth}

Our treatments effectively increased foliar $\mathrm{N}$ and $\mathrm{P}$ concentrations in A. syriaca. Foliar $\mathrm{N}$ responded linearly to $\mathrm{N}$ fertilization levels (in the caterpillar experiment, $\mathrm{N}$ fertilization effect on foliar $\mathrm{N}$ contents: $F_{1,112}=16.358$, $P<0.001$; in the aphid experiment, $F_{1,81}=12.277$, $P=0.001$ ). Foliar $P$ concentrations, on the other hand, exhibited quadratic responses to $\mathrm{P}$ fertilization (caterpillar experiment, $F_{2,110}=69.90, \quad P<0.001$; aphid experiment, $F_{2,80}=29.31, P<0.001 ;$ Fig. 1$)$. There were no interactive effects of $\mathrm{N}$ and $\mathrm{P}$ fertilization on foliar nutrient concentrations.

Plant growth increased in response to $\mathrm{N}$ addition, but not $\mathrm{P}$ addition. However, there were significant 

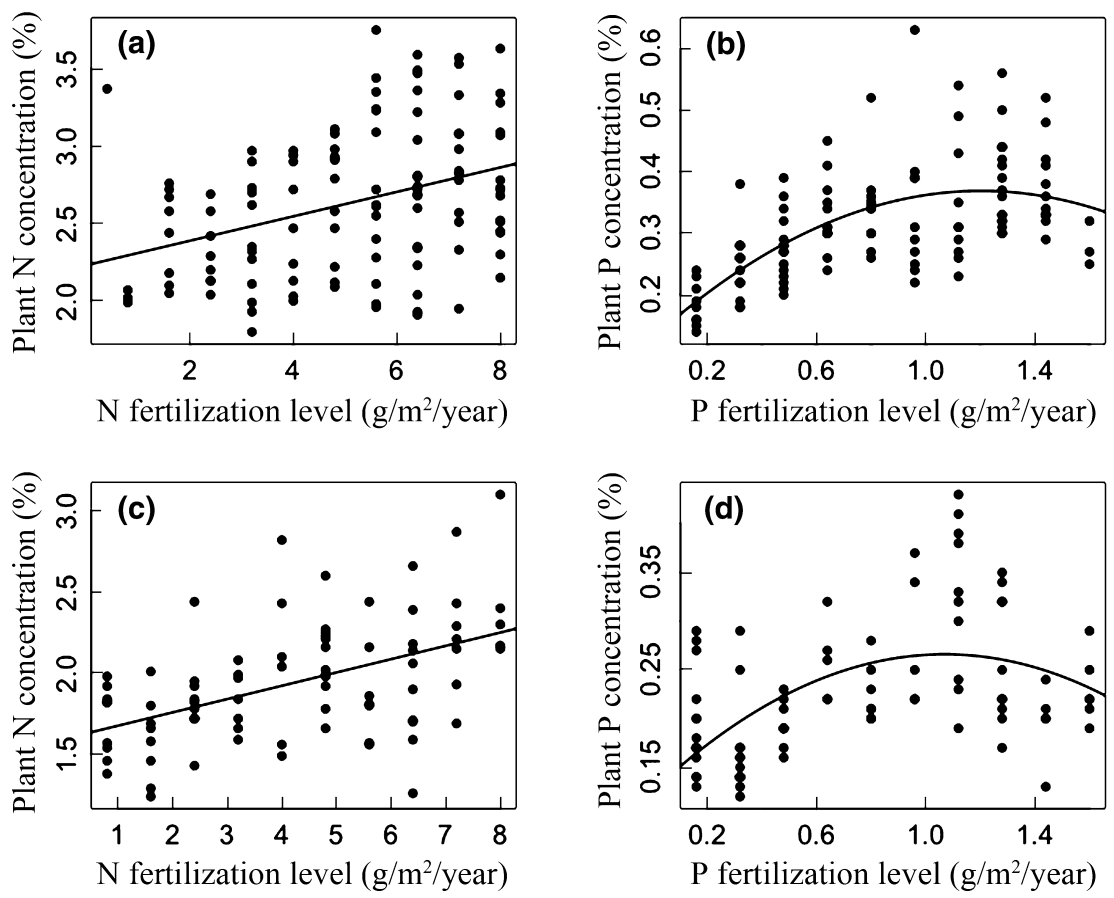

Fig. 1 Asclepias syriaca foliar $\mathrm{N}$ and $\mathrm{P}$ concentrations in response to fertilization levels in experiments with caterpillars (a, b) and aphids (c, d). Regression lines signify significant relationships.

interactions between $\mathrm{N}$ and $\mathrm{P}$ in their effects on plant growth (in the caterpillar experiment, $\mathrm{N}$ fertilization effect on plant growth, $F_{1,110}=29.95, P<0.001$; P effect, $F_{1,110}=0.98, P=0.32 ; \mathrm{N} \times \mathrm{P}$ interaction $F_{1,110}=5.87$, $P=0.017$; in the aphid experiment, $\mathrm{N}$ effect $F_{1,79}=32.77, P<0.001 ; \mathrm{P}$ effect $F_{1,79}=0.90, P=0.35$; $\mathrm{N} \times \mathrm{P}$ interaction $\left.F_{1,79}=19.14, \quad P<0.001\right)$. Purely to better illustrate visually the nature of the $\mathrm{N} \times \mathrm{P}$ interactions, we have grouped our $\mathrm{P}$ levels into three categories: (i) $0-0.5 \mathrm{~g} \mathrm{~m}^{-2} \mathrm{yr}$, (ii) $0.5-1 \mathrm{~g} \mathrm{~m}^{-2} \mathrm{yr}$, and (iii) $1-1.5 \mathrm{~g} \mathrm{~m}^{-2}$ yr. Plotting plant growth against $\mathrm{N}$ and $\mathrm{P}$ fertilization levels shows that, in both experiments, plants were more responsive to $\mathrm{P}$ addition at higher $\mathrm{N}$ fertilization levels (Fig. 2), suggesting that $\mathrm{P}$ limitation was induced by experimental $\mathrm{N}$ deposition in A. syriaca.

\section{Effects of plant $N$ and $P$ concentrations on insect performance}

D. plexippus had about the same tissue $\mathrm{N}$ concentration $(11.39 \pm 0.36 \%)$ as A. asclepiadis $(10.37 \pm 0.46 \%$,
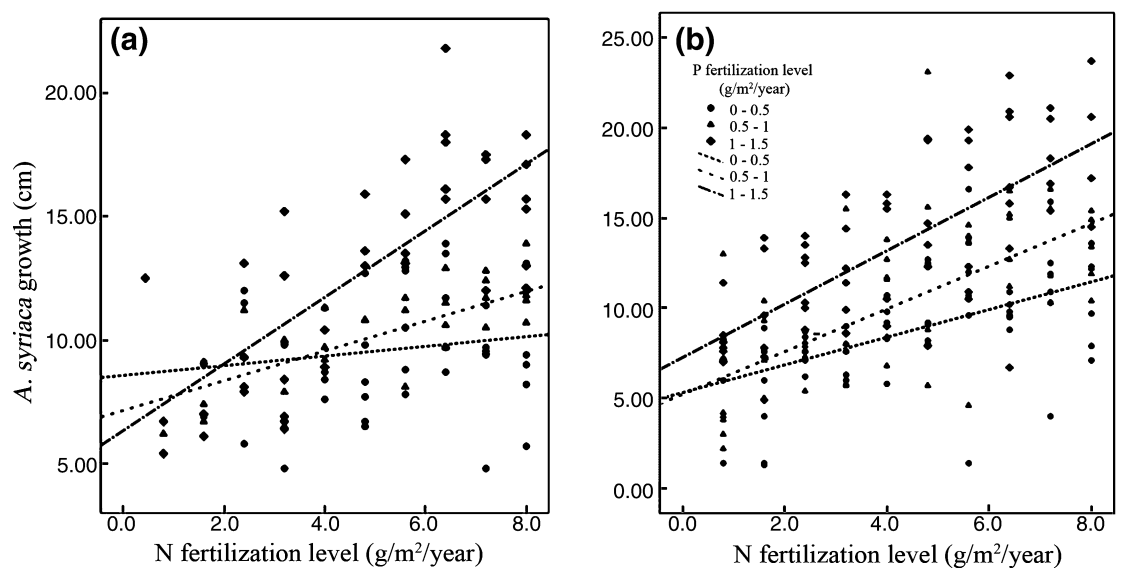

Fig. 2 Growth of A. syriaca plants in response to $\mathrm{N}$ and $\mathrm{P}$ fertilization levels in experiments with caterpillars (a) and aphids (b). Statistical analyses were conducted on 10 levels of $\mathrm{P}$ fertilization, but $\mathrm{P}$ levels are shown here in three groups for ease of illustration. 
independent sample $t$-test: $P=0.10)$, but had higher tissue $\mathrm{P}$ concentration (D. plexippus, $1.24 \pm 0.08 \%$; A. asclepiadis, $0.91 \pm 0.02 \% ; P=0.001)$. A asclepiadis exhibited a higher $\mathrm{N}: \mathrm{P}$ ratio $(25.32 \pm 1.01)$ than the average of all experimental host plants $(20.80 \pm 0.83$; $P<0.001)$, whereas $D$. plexippus had an $\mathrm{N}: \mathrm{P}$ ratio $(22.60 \pm 2.23)$ similar to the average of all host plants $(20.38 \pm 0.64 ; \quad P=0.24)$. The performance of both $D$. plexippus and $A$. asclepiadis increased with foliar $\mathrm{N}$ concentration (Fig. $3 \mathrm{a}$ and c, Table 1). Foliar P concentration had no effect on $D$. plexippus performance and actually decreased the performance of $A$. asclepiadis (Fig. $3 \mathrm{~b}$ and $\mathrm{d}$, Table 1). Critically, there were no significant interactions between $\mathrm{N}$ and $\mathrm{P}$ concentrations and subsequent herbivore performance, suggesting that high $\mathrm{N}$ availability does not increase $\mathrm{P}$ limitation.

Effects of N : P stoichiometric mismatch on insect growth We compared quadratic and linear model fits between the extents of $\mathrm{N}$ : $\mathrm{P}$ mismatch between insect
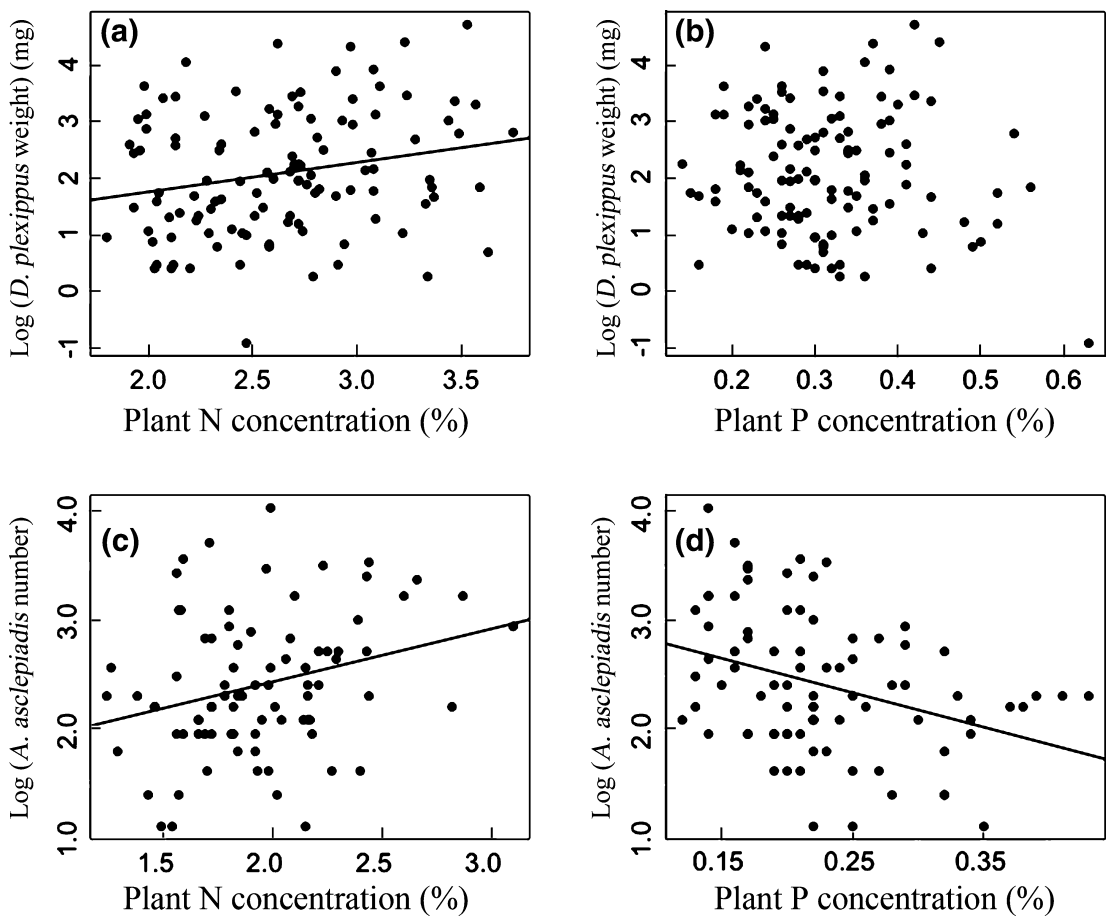

Fig. 3 Performance of D. plexippus (a, b) and A. asclepiadis (c, d) in response to foliar nitrogen and phosphorus concentrations (\%) of their host plants. Regression lines signify significant relationships.

Table 1 Effects of foliar N and P concentrations on the performance of Danaus plexippus and Aphis asclepiadis on Asclepias syriaca plants

\begin{tabular}{|c|c|c|c|c|c|c|}
\hline Species & Model & $\mathrm{df}$ & F-ratio & $P$-level & $R^{2}$ & Estimate \\
\hline \multirow[t]{4}{*}{ D.plexippus } & Full model & $3 ; 110$ & 3.14 & $0.03^{*}$ & 0.07 & \\
\hline & Nitrogen & 1 & 6.04 & $0.02^{*}$ & & $0.52(0.21)$ \\
\hline & Phosphorus & 1 & 2.27 & 0.13 & & n.s. \\
\hline & $\mathrm{N} \times \mathrm{P}$ & 1 & 1.10 & 0.30 & & n.s. \\
\hline \multirow[t]{4}{*}{ A.asclepiadis } & Full model & $3 ; 79$ & 5.41 & $0.002^{* *}$ & 0.17 & \\
\hline & Nitrogen & 1 & 7.54 & $0.008^{* *}$ & & $0.37(0.18)$ \\
\hline & Phosphorus & 1 & 8.37 & $0.005^{* *}$ & & $-2.75(0.95)$ \\
\hline & $\mathrm{N} \times \mathrm{P}$ & 1 & 0.31 & 0.58 & & n.s. \\
\hline
\end{tabular}

For each response variable, the full model degrees of freedom, F-ratio, significance level $(P)$ and variance explained $\left(R^{2}\right)$ are given. For each factor, the $F$-ratio, significance level and an estimate of the slope of the effect $( \pm \mathrm{SE})$ are given. $* P<0.05, * * P<0.01$. 

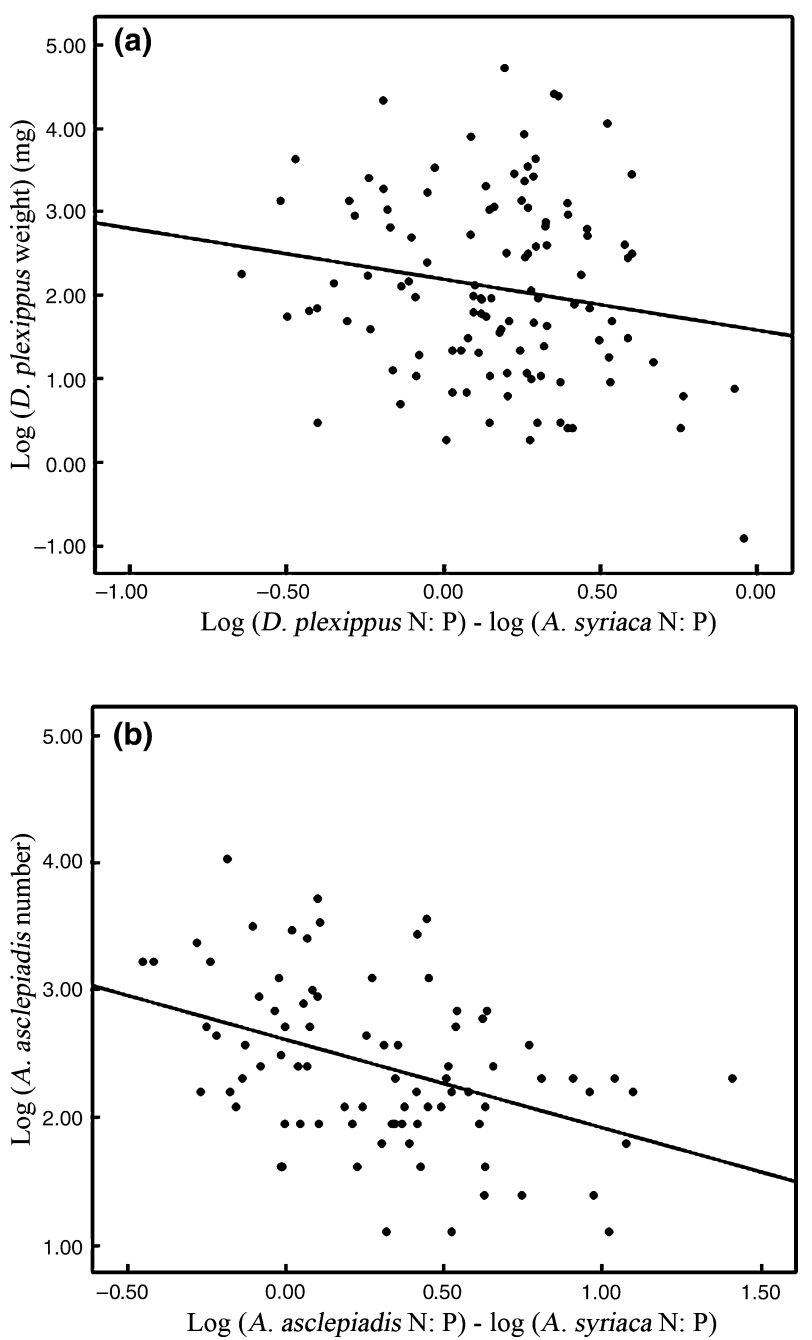

Fig. 4 Performance of D. plexippus (a) and A. asclepiadis (b) in relation to the $\mathrm{N}: \mathrm{P}$ stoichiometric mismatch between their tissues and those of their host plants. Regression lines signify significant relationships (in the case of D. plexippus, the relationship was marginally significant).

Table 2 Effects of the mismatch between plant and insect N : P and the subsequent performance of D. plexippus and A. asclepiadis

\begin{tabular}{lllcccl}
\hline Species & Model & df & $F$-ratio & $P$-level & $R^{2}$ & Estimate \\
\hline D. plexippus & Linear & $1 ; 112$ & 3.63 & 0.06 & 0.03 & $-0.62(0.32)$ \\
A. asclepiadis & Linear & $1 ; 81$ & 19.12 & $<0.001^{* * *}$ & 0.19 & $-0.04(0.008)$
\end{tabular}

For each response variable, the better fit model, degrees of freedom, $F$-ratio, significance level $(P)$ and variance explained $\left(R^{2}\right)$ are given. For each model, an estimate of the slope $( \pm \mathrm{SE})$ is given. $* * * P<0.001$.

and plant tissues and the subsequent performance of each insect species. For both species, the linear models were better fits, although the linear model was marginally nonsignificant in D. plexippus (Fig. 4, Table 2).

\section{Effects of plant $N$ and $P$ concentrations on defense production}

In both experiments, foliar $\mathrm{P}$ concentration was positively correlated with latex production, whereas foliar $\mathrm{N}$ concentration was positively correlated with cardenolide concentration (Table 3). There were marginally significant interactive effects of $\mathrm{N}$ and $\mathrm{P}$ on cardenolides. We also found a significant negative relationship between $\mathrm{N}$ and latex in the aphid experiment, but not in the caterpillar experiment. In the aphid experiment, $\mathrm{P}$ also correlated positively with trichome production, but the relationship was not significant in the caterpillar experiment (Table 3).

Decomposing direct and indirect effects of plant $N$ and $P$ on insect performance

Path analysis illustrated that for D. plexippus, the most parsimonious model included $\mathrm{P}$ as an exogenous factor and latex as the mediator (Fig. 5). Specifically, foliar $\mathrm{P}$ increased latex production, which influenced monarch growth rate negatively (Fig. 5, Table 4). In contrast, the most parsimonious path model for A. asclepiadis included only foliar $\mathrm{N}$ and $\mathrm{P}$ concentrations, reducing to the relationships illustrated previously in Fig. $3 c$ and d.

\section{Discussion}

The principle of ecological stoichiometry states that the elemental balance of resources is more important to consumers than the absolute availability of single elements (Sterner \& Elser, 2002). Therefore, the effects of varying concentrations of one element on organism performance depend upon the concentrations of other essential elements (Reich \& Schoettle, 1988). Nitrogen and phosphorus, as biologically important elements, have been shown to be limiting for both plants and terrestrial insect herbivores. This led us to explore potential increases in herbivore $\mathrm{P}$ limitation under global $\mathrm{N}$ deposition. However, we illustrate that $\mathrm{P}$ limitation of herbivores is not an inevitable consequence of anthropogenic $\mathrm{N}$ deposition in terrestrial systems. Rather, the stoichiometry of herbivore body tissues and the defensive responses of plants combine to determine the responses of herbivores to $\mathrm{P}$ availability under $\mathrm{N}$ deposition.

\section{Plant-insect N : P mismatch}

On average, terrestrial insect herbivores have a body tissue $\mathrm{N}$ : $\mathrm{P}$ ratio of 26.4 , compared with 28.0 in plants, leading to the prediction that insect $\mathrm{P}$ limitation should 
Table 3 Relationships between foliar N and P concentrations and the defensive traits of $A$. syriaca

\begin{tabular}{|c|c|c|c|c|c|}
\hline Experiment & Variable & Defense trait & $\mathrm{F}$ & $P$ & Estimate \\
\hline \multirow[t]{9}{*}{ Caterpillar } & \multirow[t]{3}{*}{$\mathrm{N}$} & Latex & 0.66 & 0.42 & - \\
\hline & & Cardenolides & 13.24 & $<0.001^{* * *}$ & $1.59(0.60)$ \\
\hline & & Trichome & 2.021 & 0.158 & - \\
\hline & \multirow[t]{3}{*}{$\mathrm{P}$} & Latex & 10.35 & $0.002^{* *}$ & $2.798(0.884)$ \\
\hline & & Cardenolides & 1.52 & 0.221 & - \\
\hline & & Trichome & 0.01 & 0.91 & - \\
\hline & \multirow[t]{3}{*}{$\mathrm{N} \times \mathrm{P}$} & Latex & 2.28 & 0.135 & - \\
\hline & & Cardenolides & 2.88 & 0.093 & $-2.96(0.09)$ \\
\hline & & Trichome & 0.004 & 0.95 & - \\
\hline \multirow[t]{9}{*}{ Aphid } & \multirow[t]{3}{*}{$\mathrm{N}$} & Latex & 5.72 & $0.02^{*}$ & $-1.41(0.69)$ \\
\hline & & Cardenolides & 3.56 & 0.06 & $2.27(0.92)$ \\
\hline & & Trichome & 0.02 & 0.88 & - \\
\hline & \multirow[t]{3}{*}{$\mathrm{P}$} & Latex & 6.00 & $0.02^{*}$ & $3.12(1.10)$ \\
\hline & & Cardenolides & 2.71 & 0.10 & - \\
\hline & & Trichome & 7.66 & 0.007 & $7.583(2.756)$ \\
\hline & \multirow[t]{3}{*}{$\mathrm{N} \times \mathrm{P}$} & Latex & 2.41 & 0.12 & - \\
\hline & & Cardenolides & 3.58 & 0.06 & $-7.10(3.75)$ \\
\hline & & Trichome & 0.33 & 0.57 & - \\
\hline
\end{tabular}

For each response variable, the $F$-ratio, significance level $(P)$ and estimate of the slope of the effect $( \pm$ SE) are given. ${ }^{*} P<0.05,{ }^{* *} P<0.01,{ }^{* * *} P<0.001$.

be at least as severe as $\mathrm{N}$ limitation (Elser et al., 2000). In our system, however, the $\mathrm{N}: \mathrm{P}$ ratio of $A$. asclepiadis (26.2) was much higher than that of the average foliage of the host plant, $A$. syriaca (21.3). One concern with such a comparison for aphids is that phloem sap stoichiometry may be different from that of leaf tissues. Although we could find no study to date directly comparing leaf and phloem $\mathrm{N}$ : P ratios, we can combine several independent studies to explore the issue. For example, the castor bean, Ricinus communis, has often been used to study phloem exudates. Calculations based on a review summarizing 20 years of study in this species suggested that the molar $\mathrm{N}$ : Pi ratio in leaf tissue is 50, whereas the $\mathrm{N}$ : Pi ratio in phloem exudate is 10.38 (Peuke, 2010). Assuming Pi comprises $25 \%$ of total P in terrestrial plants (Hidaka \& Kitayama, 2011), and $73 \%$ of total $\mathrm{P}$ in phloem exudates (Hall \& Baker, 1972), the N : P ratio in leaves is 12.5 compared with 7.58 in the phloem of $R$. communis. If phloem $\mathrm{N}: \mathrm{P}$ ratios are also lower than foliar $\mathrm{N}: \mathrm{P}$ ratios in our milkweed system, this would further exacerbate $\mathrm{N}$ limitation on $A$. asclepiadis, with its high body $\mathrm{N}: \mathrm{P}$ ratio. Our results suggest that $\mathrm{N}$ deposition does not induce $\mathrm{P}$ limitation in A. asclepiadis because $\mathrm{N}$ requirements surpass $\mathrm{P}$ demand even at $\mathrm{N}$ deposition levels of $8 \mathrm{~g} \mathrm{~m}^{-2} \mathrm{yr}$. This is illustrated in Fig. $4 \mathrm{~b}$ by the paucity of data points with negative values on the $x$-axis; despite profound manipulation of plant $\mathrm{N}$ : P stoichiometry, a great majority of aphids are still $\mathrm{N}$ limited at high $\mathrm{N}$ availability.

Not only did we fail to find evidence for P limitation in $A$. asclepiadis but also there was actually a negative relationship between plant $\mathrm{P}$ content and insect growth (Table 1). To meet their requirements for the most limiting resource (in this case, $\mathrm{N}$ ), herbivorous insects may consume higher than necessary concentrations of other nutrients (Simpson et al., 2004). These surplus resources are subsequently stored or excreted at the expense of energy (Boersma \& Elser, 2006). Declines in aphid performance with increasing $\mathrm{P}$ availability may represent costs associated with eliminating excess $\mathrm{P}$, whereas meeting the demand for N. Such costs of excreting excess nutrients have been reported previously for Aphis nerii on milkweed (Zehnder \& Hunter, 2009).

Compared with A. asclepiadis, D. plexippus has a higher body $\mathrm{P}$ concentration and therefore a lower $\mathrm{N}$ : $\mathrm{P}$ ratio, closer to that of its host plant. This is consistent with Woods et al. (2004) who suggest that Lepidoptera are generally richer in $\mathrm{P}$ than are other insect lineages. According to our original predictions, the close match between monarch and milkweed N : P ratios should increase the likelihood of observing $\mathrm{P}$ limitation under $\mathrm{N}$ deposition. Indeed, $\mathrm{P}$ limitation has been reported in other Lepidoptera. For example, tobacco hornworm, Manduca sexta, grows faster on $\mathrm{P}$ rich jimsonweed Datura wrightii (Perkins et al., 2004). Likewise, in western spruce budworm Choristoneura occidentalis, survival rate is optimal on dietary $\mathrm{P}$ levels higher than those of their natural host trees (Clancy \& King, 1993). By contrast, we did not find evidence of $\mathrm{P}$ limitation in D. plexippus. Interestingly, the reason was not insensitivity to $\mathrm{P}$ per se, but rather through the intermediate effects of $\mathrm{P}$ on plant defense (Fig. 5). P addition 

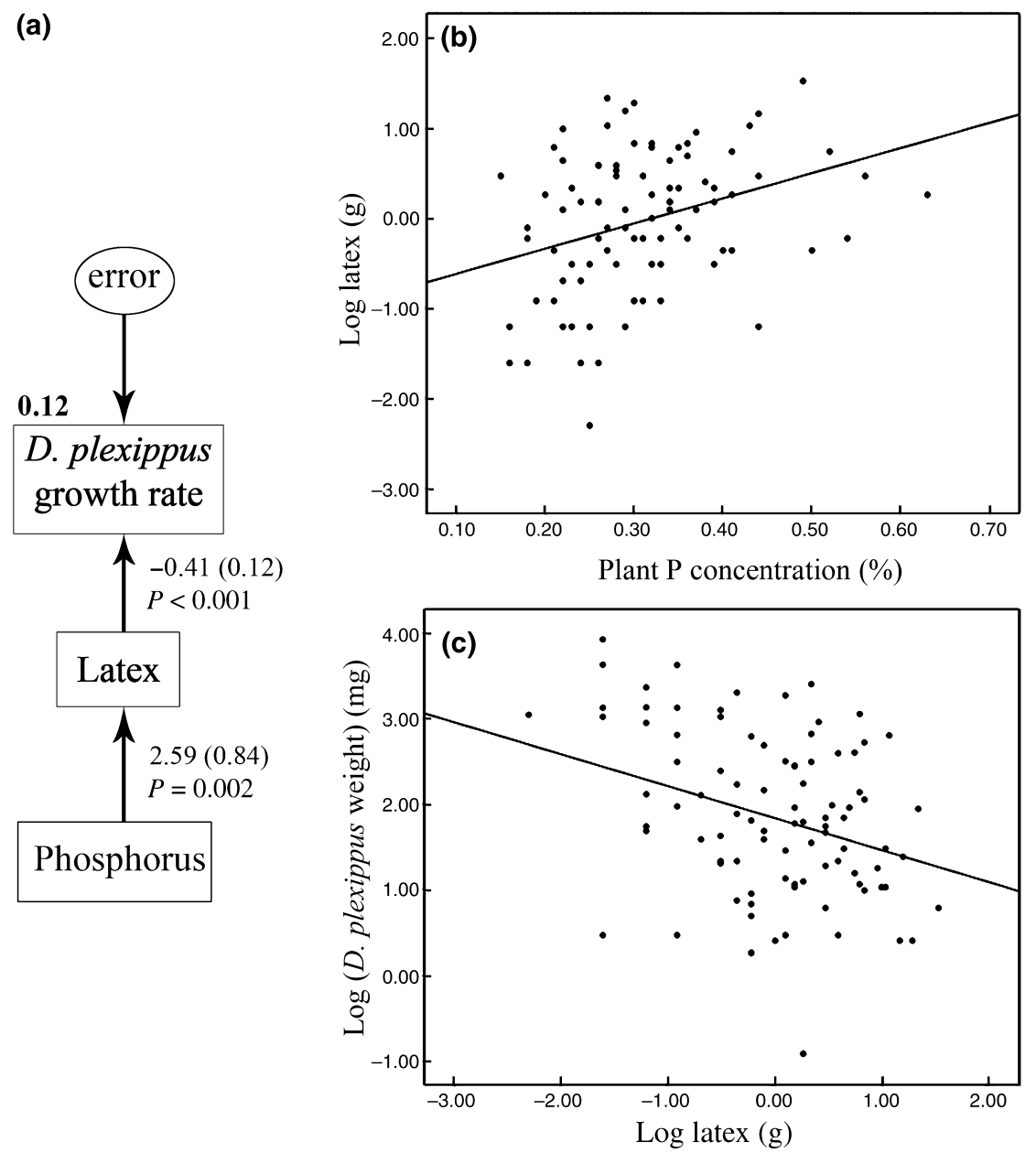

Fig. 5 Path analysis of the effects of foliar N and P concentrations on the growth rate of D. plexippus. (a) Path diagram for the most parsimonious model. Unstandardized path coefficients (SD in parenthesis) are given beside each arrow. The bold number indicates the variance explained by the model. (b) Relationship between foliar P concentration and latex production in Asclepias syriaca. (c) Negative association between latex production in Asclepias syriaca and the growth rate of D. plexippus larvae.

Table 4 Path analysis model selection

\begin{tabular}{lccccc}
\hline Model & df & $\chi^{2}$ & $P$ & AIC & $R^{2}$ \\
\hline Saturated model & & & & 42.00 & 0.17 \\
Most parsimonious model & 1 & 0.79 & 0.38 & 10.79 & 0.12 \\
\hline
\end{tabular}

df, degrees of freedom; AIC, Akaike information criteria. $P$ is the significance level of the model fit, $R^{2}$ is the variance explained by the model.

appears to favor the production of latex (Table 3), which is known to reduce the performance of monarch caterpillars (Zalucki \& Malcolm, 1999).

To date, the majority of evidence of $\mathrm{P}$ limitation in herbivores is found in aquatic systems. Compared with terrestrial herbivores, zooplankton and aquatic insect herbivores are more likely to be P-limited (Sterner et al.,
1993; Elser et al., 2001; Frost \& Elser, 2002). Aquatic ecosystems have lower available $\mathrm{P}$, therefore $\mathrm{N}$ : $\mathrm{P}$ ratios of phytoplankton and other autotrophs can be from 1.5 to 4 times higher than those of aquatic herbivores, whereas average $\mathrm{N}: \mathrm{P}$ ratios of plants are only 1.1 times higher than those of terrestrial insects (Cross et al., 2003). Therefore, herbivores in aquatic systems should have a higher probability of $\mathrm{P}$ limitation when compared with terrestrial herbivores, which are more likely to be $\mathrm{N}$ and $\mathrm{P}$ colimited.

\section{Nitrogen, phosphorus and plant chemical defense}

Plant nutrient status can affect the expression of plant chemical defense by changing relative allocation among growth, storage and defense (Bryant et al., 1983; Herms \& Mattson, 1992; Vannette \& Hunter, 2011b). Intensive studies on the effects of $\mathrm{N}$ have shown that plant phen- 
olics tend to decrease following $\mathrm{N}$ deposition (Koricheva $e t$ al., 1998), although the effects of $P$ on defense are less frequently reported and show inconclusive results. $P$ availability should be vital to plant defense expression for several reasons. First, P status influences plant carbon metabolism by affecting photosynthesis and carbon reserves (Warren \& Adams, 2002). Second, many intermediates in the pathways of secondary metabolite synthesis contain P (Gershenzon, 1994), and allocation among these pathways may vary with $\mathrm{P}$ availability (Plaxton \& Carswell, 1999). Third, plants must expend energy in the form of ATP to store defense chemicals (Gershenzon, 1994) including latex defenses such as those of A. syriaca. Given that there is accumulating evidence that many plants change from $\mathrm{N}$ to $\mathrm{P}$ limitation under $\mathrm{N}$ deposition, there needs to be more exploration of the effects of $\mathrm{P}$ on plant defenses.

Unfortunately, there is currently a lack of integration between the fields of elemental stoichiometry and plant defense theory in the literature. In plant cells, $\mathrm{N}$ and $\mathrm{P}$ metabolism are linked because the majority of cellular $\mathrm{P}$ is used for translating amino acids into proteins, so $\mathrm{P}$ availability can regulate $\mathrm{N}$ dynamics in cells (Warren \& Adams, 2002). In addition, $\mathrm{N}$ use efficiency depends on P availability (Reich et al., 2009). In Pinus strobus, for example, $\mathrm{N}$ use efficiency is negatively related to the cellular $\mathrm{N}$ : $\mathrm{P}$ ratio, suggesting that $\mathrm{P}$ is a major regulator of $\mathrm{N}$ activity in plant cells (Reich \& Schoettle, 1988). Therefore, the mechanisms by which the addition of $\mathrm{N}$ and $\mathrm{P}$ affect plant chemistry are complex and context dependent. Herein, we report that in both aphid and caterpillar experiments, $\mathrm{P}$ is positively correlated with latex production, whereas $\mathrm{N}$ is positively correlated with foliar cardenolide concentration. As a result, variations in cell $\mathrm{N}$ and $\mathrm{P}$ concentrations not only can affect the absolute amounts of plant defense but also the relative expression of different defense traits.

\section{Nitrogen deposition and herbivorous insect communities}

Long-term studies on the effects of $\mathrm{N}$ deposition on community composition of herbivorous insects have mainly focused on how changes in plant chemistry, productivity and diversity influence insects (Siemann, 1998; Haddad et al., 2000). However, even after controlling for the above variables, insect species vary in their responses to $\mathrm{N}$ enrichment of single host plant species (Lightfoot \& Whitford, 1987; Strauss, 1987; Cornelissen \& Stiling, 2006). The differential responses have been ascribed to variation in life history traits and interactions with other trophic levels (Strauss, 1987; White, 1993). Herein, we suggest that constraints of stoichiometric mismatch and plant defense compounds may also play a role. As patterns of plant resource allocation and defense are in turn influenced by herbivore feeding (Karban \& Baldwin, 1997; Tao \& Hunter, 2011), future study should consider feedbacks between plant and herbivore performance under $\mathrm{N}$ deposition and variable $P$ availability.

\section{Acknowledgements}

This work was supported by an Edwin. S. George Reserve Scholarship from the University of Michigan to LT and NSF DEB-0814340 to MDH. We gratefully acknowledge M. Palmer for assistance in greenhouse arrangements. We also thank S. Kabat, H. DeRose-Wilson and B. Chen for helping with laboratory and field work. Helpful comments on a previous draft were provided by E. Pringle, E. Wason, the UM plant ecology discussion group and two anonymous referees.

\section{References}

Aber JD, Nadelhoffer KJ, Steudler P, Melillo JM (1989) Nitrogen saturation in northern forest ecosystems. BioScience, 39, 378-386.

Bertram SM, Schade JD, Elser JJ (2006) Signalling and phosphorus: correlations between mate signalling effort and body elemental composition in crickets. Animal Behaviour, 72, 899-907.

Bobbink R, Hicks K, Galloway J et al. (2010) Global assessment of nitrogen deposition effects on terrestrial plant diversity: a synthesis. Ecological Applications, 20, 30-59.

Boersma M, Elser JJ (2006) Too much of a good thing: on stoichiometrically balanced diets and maximal growth. Ecology, 87, 1325-1330.

Bryant JP, Chapin FS, Klein DR (1983) Carbon nutrient balance of boreal plants in relation to vertebrate herbivory. Oikos, 40, 357-368.

Burnham KP, Anderson DR (2002) Model Selection and Multimodel Inference: A Practical Information-Theoretic Approach. Springer-Verlag, New York.

Clancy KM, King RM (1993) Defining the western spruce budworms nutritional niche with response-surface methodology. Ecology, 74, 442-454.

Cornelissen T, Stiling P (2006) Responses of different herbivore guilds to nutrient addition and natural enemy exclusion. Ecoscience, 13, 66-74.

Cross WF, Benstead JP, Rosemond AD, Wallace JB (2003) Consumer-resource stoichiometry in detritus-based streams. Ecology Letters, 6, 721-732.

Elser JJ, Fagan WF, Denno RF et al. (2000) Nutritional constraints in terrestrial and freshwater food webs. Nature, 408, 578-580.

Elser JJ, Hayakawa K, Urabe J (2001) Nutrient limitation reduces food quality for zooplankton: Daphnia response to seston phosphorus enrichment. Ecology, 82, 898 903.

Emon JV, Seiber JN (1985) Chemical constituents and energy content of two milkweeds, Asclepias speciosa and A. curassavica. Economic Botany, 39, 47-55.

Fagan WF, Siemann E, Mitter C, Denno RF, Huberty AF, Woods HA, Elser JJ (2002) Nitrogen in insects: implications for trophic complexity and species diversification. American Naturalist, 160, 784-802.

Feller IC (1995) Effects of nutrient enrichment on growth and herbivory of dwarf red mangrove (Rhizophora mangle). Ecological Monographs, 65, 477-505.

Fischer RS, Bonner CA, Theodorou ME, Plaxton WC, Hrazdina G, Jensen RA (1993) Response of aromatic pathway enzymes of plant suspension cells to phosphate limitation. Bioorganic and Medicinal Chemistry Letters, 3, 14151420 .

Frost PC, Elser JJ (2002) Growth responses of littoral mayflies to the phosphorus content of their food. Ecology Letters, 5, 232-240.

Galloway JN, Dentener FJ, Capone DG et al. (2004) Nitrogen cycles: past, present, and future. Biogeochemistry, 70, 153-226.

Gershenzon J (1994) Metabolic costs of terpenoid accumulation in higher-plants. Journal of Chemical Ecology, 20, 1281-1328.

Haddad NM, Haarstad J, Tilman D (2000) The effects of long-term nitrogen loading on grassland insect communities. Oecologia, 124, 73-84.

Hall SM, Baker DA (1972) Chemical composition of Ricinus phloem exudate. Planta, 106, 131-140.

Harborne JB (1991) The chemical basis of plant defense. In: Plant Defenses Against Mammalian Herbivory (eds Palo RT, Robbins CT), pp. 45-59. CRC Press, Boca Raton. 
Herms DA, Mattson WJ (1992) The dilemma of plants - to grow or defend. Quarterly Review of Biology, 67, 283-335.

Hidaka A, Kitayama K (2011) Allocation of foliar phosphorus fractions and leaf traits of tropical tree species in response to decreased soil phosphorus availability on Mount Kinabalu, Borneo. Journal of Ecology, 99, 849-857.

Hillebrand H, Borer ET, Bracken MES et al. (2009) Herbivore metabolism and stoichiometry each constrain herbivory at different organizational scales across ecosystems. Ecology Letters, 12, 516-527.

Huberty AF, Denno RF (2006) Consequences of nitrogen and phosphorus limitation for the performance of two planthoppers with divergent life-history strategies. Oecologia, 149, 444 455.

Jones CG, Hartley SE (1999) A protein competition model of phenolic allocation. Oikos, 86, 27-44.

Karban R, Baldwin IT (1997) Induced Responses to Herbivory. The University of Chicago Press, Chicago.

Koricheva J, Larsson S, Haukioja E, Keinanen M (1998) Regulation of woody plant secondary metabolism by resource availability: hypothesis testing by means of meta-analysis. Oikos, 83, 212-226.

Levin DA (1973) Role of trichomes in plant defense. Quarterly Review of Biology, 48, 3 15 .

Lightfoot DC, Whitford WG (1987) Variation in insect densities on desert creosotebush - is nitrogen a factor? Ecology, 68, 547-557.

Mattson WJ (1980) Herbivory in relation to plant nitrogen-content. Annual Review of Ecology and Systematics, 11, 119-161.

Mooney KA, Jones P, Agrawal AA (2008) Coexisting congeners: demography, competition, and interactions with cardenolides for two milkweed-feeding aphids. Oikos, 117, 450-458

Morecroft MD, Sellers EK, Lee JA (1994) An experimental investigation into the effects of atmospheric nitrogen deposition on two semi-natural grasslands. Journal of Ecology, 82, 475-483.

Pennings SC, Clark CM, Cleland EE et al. (2005) Do individual plant species show predictable responses to nitrogen addition across multiple experiments? Oikos, 110, 547-555.

Peñuelas J, Sardans J, Rivas-Ubach A, Janssens IA (2012) The human-induced imbalance between C, N and P in Earth's life system. Global Change Biology, 18, 3-6.

Perkins MC, Woods HA, Harrison JF, Elser JJ (2004) Dietary phosphorus affects the growth of larval Manduca sexta. Archives of Insect Biochemistry and Physiology, 55, 153-168.

Persson J, Fink P, Goto A, Hood JM, Jonas J, Kato S (2010) To be or not to be what you eat: regulation of stoichiometric homeostasis among autotrophs and heterotrophs. Oikos, 119, 741-751

Peuke AD (2010) Correlations in concentrations, xylem and phloem flows, and partitioning of elements and ions in intact plants. A summary and statistical re-evaluation of modelling experiments in Ricinus communis. Journal of Experimental Botany, 61, 635-655.

Plaxton WC, Carswell MC (1999) Metabolic aspects of the phosphate starvation response in plants. In: Plant Responses to Environmental Stresses: From Phytohormones to Gene Reorganization (ed. Lerner HR), pp. 349-372. Marcel Dekker, New York.

R Development Core Team (2011) R: A Language and Environment for Statistical Computing, Version 2.13.2., Vienna, Austria. Available at: http://www.r-project. org (accessed 1 October 2011).

Raubenheimer D, Simpson SJ (1997) Integrative models of nutrient balancing: application to insects and vertebrates. Nutrition Research Reviews, 10, 151-179.
Reich PB, Schoettle AW (1988) Role of phosphorus and nitrogen in photosynthetic and whole plant carbon gain and nutrient use efficiency in eastern white-pine. Oecologia, 77, 25-33.

Reich PB, Oleksyn J, Wright IJ (2009) Leaf phosphorus influences the photosynthesisnitrogen relation: a cross-biome analysis of 314 species. Oecologia, 160, 207-212.

Sardans J, Rivas-Ubach A, Peñuelas J (2011) The elemental stoichiometry of aquatic and terrestrial ecosystems and its relationships with organismic lifestyle and ecosystem structure and function: a review and perspectives. Biogeochemistry, doi: 10.1007/s10533-011-9640-9.

Seiber JN, Nelson CJ, Lee SM (1982) Cardenolides in the latex and leaves of seven Asclepias species and Calotropis procera. Phytochemistry, 21, 2343-2348.

Siemann E (1998) Experimental tests of effects of plant productivity and diversity on grassland arthropod diversity. Ecology, 79, 2057-2070.

Simpson SJ, Sibly RM, Lee KP, Behmer ST, Raubenheimer D (2004) Optimal foraging when regulating intake of multiple nutrients. Animal Behaviour, 68, 1299-1311.

Speight MR, Hunter MD, Watt AD (2008) Ecology of Insects: Concepts and Applications. Wiley-Blackwell, West Sussex.

Sterner RW, Elser JJ (2002) Ecological Stoichiometry: The Biology of Elements from Molecules to the Biosphere. Princeton University Press, Princeton.

Sterner RW, Hagemeier DD, Smith WL (1993) Phytoplankton nutrient limitation and food quality for Daphnia. Limnology and Oceanography, 38, 857-871.

Strauss SY (1987) Direct and indirect effects of host-plant fertilization on an insect community. Ecology, 68, 1670-1678.

Tao L, Hunter MD (2011) Effects of insect herbivores on the nitrogen economy of plants. In: Ecological Aspects of Nitrogen Metabolism in Plants (eds Polacco JC, Todd CD), pp. 257-279. John Wiley \& Sons, Inc., Hoboken.

Throop HL, Lerdau MT (2004) Effects of nitrogen deposition on insect herbivory: implications for community and ecosystem processes. Ecosystems, 7, 109-133.

Vannette RL, Hunter MD (2011a) Genetic variation in expression of defense phenotype may mediate evolutionary adaptation of Asclepias syriaca to elevated $\mathrm{CO}_{2}$ Global Change Biology, 17, 1277-1288.

Vannette RL, Hunter MD (2011b) Plant defence theory re-examined: nonlinear expectations based on the costs and benefits of resource mutualisms. Journal of Ecology 99, 66-76.

Vitousek PM, Mooney HA, Lubchenco J, Melillo JM (1997) Human domination of Earth's ecosystems. Science, 277, 494-499.

Vitousek PM, Porder S, Houlton BZ, Chadwick OA (2010) Terrestrial phosphorus limitation: mechanisms, implications, and nitrogen-phosphorus interactions. Ecological Applications, 20, 5-15.

Warren CR, Adams MA (2002) Phosphorus affects growth and partitioning of nitrogen to Rubisco in Pinus pinaster. Tree Physiology, 22, 11-19.

Watts T, Woods HA, Hargand S, Elser JJ, Markow TA (2006) Biological stoichiometry of growth in Drosophila melanogaster. Journal of Insect Physiology, 52, 187-193.

White TCR (1993) The Inadequate Environment: Nitrogen and the Abundance of Animals. Springer-Verlag, Berlin and New York.

Woods HA, Perkins MC, Elser JJ, Harrison JF (2002) Absorption and storage of phosphorus by larval Manduca sexta. Journal of Insect Physiology, 48, 555-564.

Woods HA, Fagan WF, Elser JJ, Harrison JF (2004) Allometric and phylogenetic variation in insect phosphorus content. Functional Ecology, 18, 103-109.

Zalucki MP, Malcolm SB (1999) Plant latex and first-instar monarch larval growth and survival on three North American milkweed species. Journal of Chemical Ecol$o g y, 25,1827-1842$.

Zehnder CB, Hunter MD (2009) More is not necessarily better: the impact of limiting and excessive nutrients on herbivore population growth rates. Ecological Entomology, 34, 535-543. 